Arch. Dis. Childh., 1964, 39, 26.

\title{
PNEUMOCYSTIS CARINII PNEUMONIA AND PROGRESSIVE VACCINIA IN SIBLINGS
}

\author{
BY
}

\author{
E. C. ALLIBONE, W. GOLDIE and B. P. MARMION* \\ From the Department of Paediatrics, St. James's Hospital, Leeds, and the Public Health Laboratory, Leeds
}

(RECEIVED FOR PUBLICATION JULY 18, 1963)

The occurrence of Pneumocystis carinii pneumonia and progressive vaccinia in siblings, associated with hypogammaglobulinaemia, has already been recorded (McKay and Richardson, 1959). A similar combination in siblings described here seems worthy of record, because the gamma globulin value in the sib with progressive vaccinia was probably within normal limits, and in both patients there seems to have been a failure of maturation of lymphocytes.

\section{Case Reports}

Case 1: Pneumocystis carinii Infestation of Lung. J.S., a girl, was born on July 20, 1958, the first child of parents who were first cousins. She progressed normally and on September 10 she was vaccinated. As no reaction developed, she was revaccinated eight days later, but again there was no 'take'. At the age of 9 months she developed a cough, which became paroxysmal and distressing. After three weeks she was admitted to hospital because of increasing respiratory distress and cyanosis.

Examination of the chest revealed a generalized reduction of air entry and on $x$-ray examination a diffuse opacity was seen throughout both lung fields. Leucocytes were 17,800 per c.mm., of which $80 \%(14,240)$ were neutrophils, $14 \%(2,492)$ lymphocytes and $6 \%(1,068)$ monocytes. Serum gamma globulin was not estimated.

In spite of treatment with chloramphenicol and cortisone and subsequently with erythromycin and novobiocin, the respiratory reserve progressively diminished. Death occurred seven days after admission.

Autopsy revealed a well-nourished infant.

RESPIRATORY SySTEM. There was slight hyperaemia of the mucosa of the air passages. The right lung weighed $165 \mathrm{~g}$. and the left $140 \mathrm{~g}$. Both were completely consolidated except along the anterior borders, where there were small areas of aeration. On section they were greyish-pink in colour and had the consistency of liver. They appeared to be neither purulent nor congested.

Other organs were normal, apart from congestion. No note was made of the presence or size of the thymus.

\footnotetext{
* Present address: Monash University, Melbourne, Australia.
}

Histology. In numerous blocks taken from both lungs alveoli were seen to be completely filled by foamy exudate. Only a few macrophages were seen in the alveoli and in their walls occasional polymorphs were present. No plasma cells were seen in any of the blocks examined. Bacteria were absent. Sections were stained by Gomori's methenamine-silver nitrate techniques and circular bodies resembling Pneumocystis carinii were identified in alveoli (Fig. 1). In the spleen there was a notable absence of mature lymphocytes (Fig. 2). Malpighian bodies were clearly visible, but they consisted largely of reticulum cells with very few surrounding lymphocytes. In the pulp too, lymphocytes were very scanty. The cellular component of hilar lymph nodes consisted largely of reticulum cells, with few mature lymphocytes. Histology of other tissues showed no relevant abnormality.

There seems to be no doubt that this was a Pneumocystis carinii infestation, but the absence of the plasma cell and lymphocyte exudate usually associated with this condition was striking.

Case 2: Progressive Vaccinia. The second child (G.S.), a boy, was born on January 1, 1960. He developed normally and on March 17 he was vaccinated on the left upper arm with an apparently normal 'take'. Three weeks later he developed diarrhoea and vomiting and he was admitted to hospital on April 23, 1960 . It was then noticed that the vaccination pustule had not developed in the normal way and there was an ulcer at the site measuring $3.5 \times 2.5 \mathrm{~cm}$. The diarrhoea and vomiting cleared rapidly, but on May 1 fresh vesicles appeared on the left ear and on the scrotum. Vesicles subsequently appeared on the left heel, the buttocks, the forehead, the occiput and a number of other areas, and by May 27 great numbers of vesicles were present all over the body and on the palate. On May 11 the testes were swollen and hard. During this time he ran a persistent pyrexia and at the time of his death on June 21 the ulcer at the site of vaccination had reached a size of $5 \times 4 \mathrm{~cm}$. Slight jaundice was first noted on June 9 and persisted until death.

ReleVANT INVESTigations. Estimation of the serum gamma globulin before treatment was carried out by 


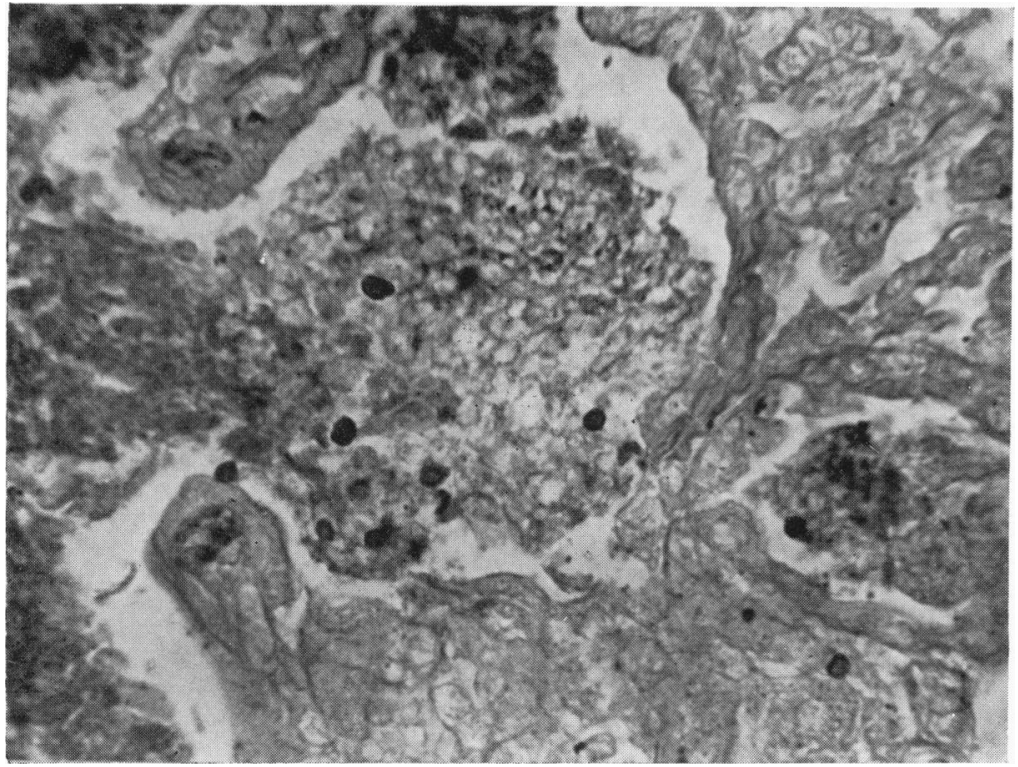

three methods on a sample collected on May 5. (a) By immunoelectrophoresis (Dr. J. F. Soothill, Birmingham University): a value of $200 \mathrm{mg}$. per $100 \mathrm{ml}$. for the $7 \mathrm{~S}$ gamma globulin was found. (b) By dye-binding capacity after separation of protein fractions by paper electro-

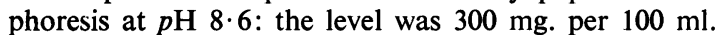
(c) By its ability to neutralize the anti-gamma-globulin fraction of anti-human globulin serum (Coombs reagent) as tested against sensitized red cells and compared with a standard gamma globulin preparation: a level of 120 mg. per $100 \mathrm{ml}$. was obtained.

The serum gamma globulin of both parents was shown by the second method to be normal; values of 520 and $840 \mathrm{mg}$. per $100 \mathrm{ml}$. were found for the mother and father respectively.

Other Haematological Observations. On May 5, 1960 , the haemoglobin was $9 \cdot 28 \mathrm{~g} . / 100 \mathrm{ml}$. $(62 \%)$. White cells numbered 3,400/c.mm.; neutrophils $75 \%$,

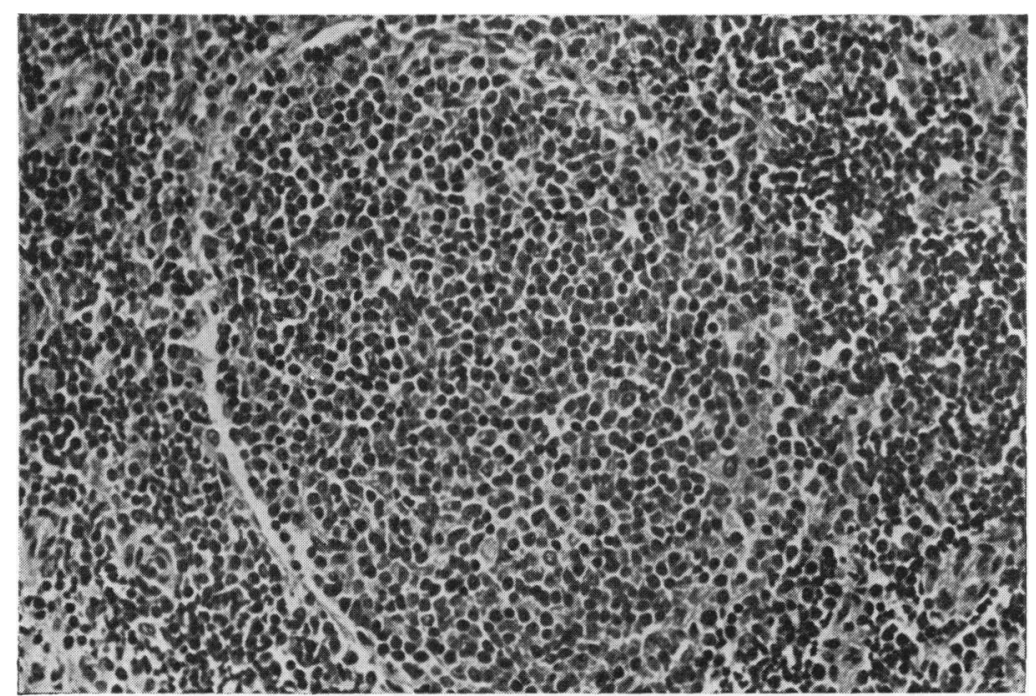

FIG. 2.-Section of spleen from Case 1. (Haematoxylin and eosin $\times 130$.) Mature lymphocytes are fewer than normal. 


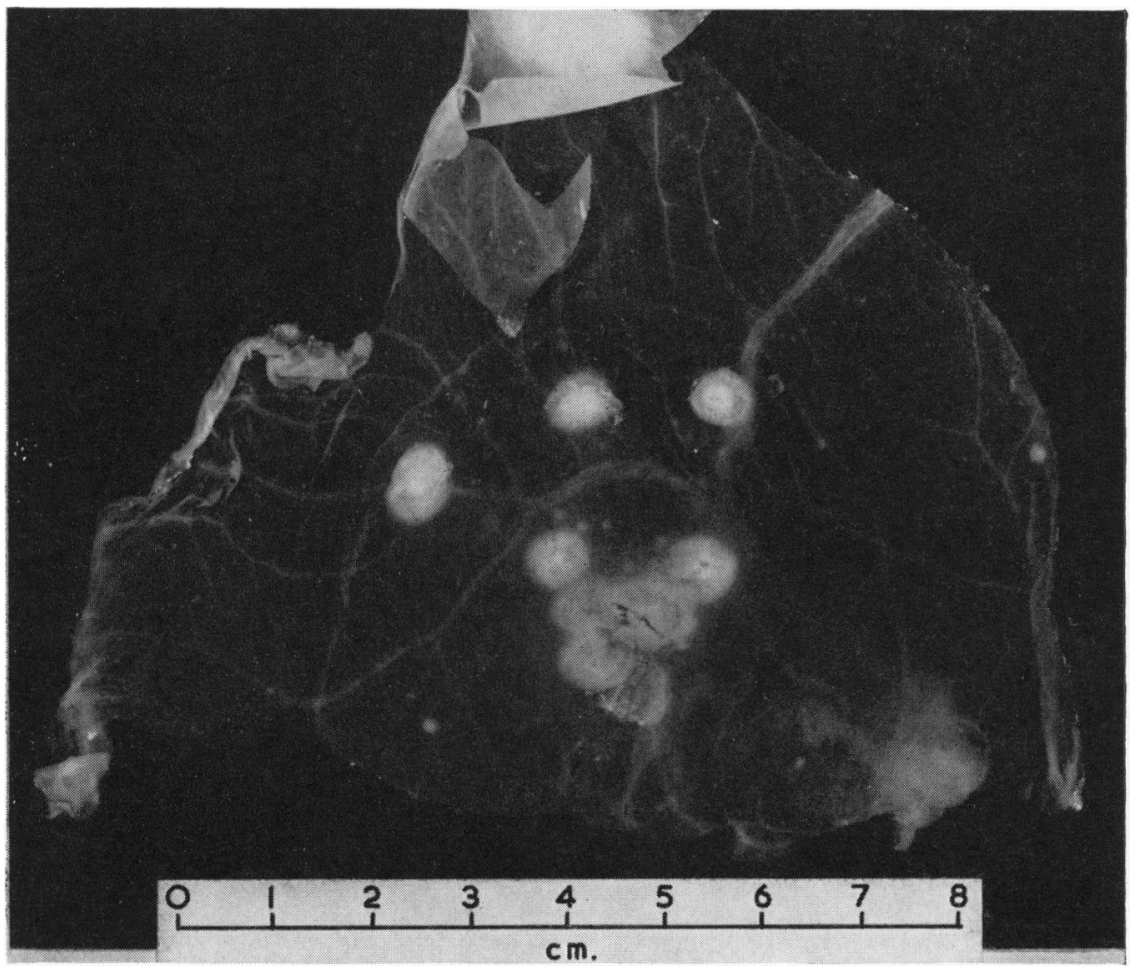

FIG. 3.-Pocks growing on chorioallantoic membrane inoculated with ground-up blood clot from Case 2.

2,550/c.mm.; eosinophils $1 \%, 34 /$ c.mm.; lymphocytes $20 \%, 680 /$ c.mm.; monocytes $4 \%, 136 /$ c.mm.

In subsequent leucocyte counts, the absolute number of lymphocytes remained below $600 / \mathrm{c} . \mathrm{mm}$. except on one occasion, when they were 1,818 in a total leucocyte count of 10,100 .

On June 25, blood group A rhesus positive. Anti-B isoagglutinin could not be demonstrated in the serum.

\section{Virological INVESTIGATIONS}

During Life. Vesicle fluid and scrapings were collected on May 5 from a fresh lesion on the back of the neck and from the ulcer at the site of inoculation. A sample of blood was also taken. Chorioallantoic membranes of 11-day-old chick embryos were inoculated with the material from the lesions and typical vaccinial pocks obtained. Six pocks were also found on a membrane inoculated with ground-up clot from the blood sample; it had been taken 49 days after vaccination (Fig. 3). An extract of the membrane inoculated with the material from the lesion on the back of the neck fixed complement at a dilution of 1 in 160 with serum from a rabbit hyperimmunized with vaccinia virus, but did not fix at a dilution of 1 in 10 with normal rabbit serum. The strain of vaccinia virus was tested by Dr. D. J. Bauer (Wellcome Laboratories of Tropica]
Medicine) and found to be sensitive to $\mathrm{N}$-methylisatin $\beta$-thiosemicarbazone (see below).

The serum from the blood sample taken on May 5 was titrated by two methods for neutralizing antibody to the vaccinia virus. In the first a $1 / 2 \cdot 5$ dilution of the inactivated serum was mixed with that dilution of the vaccinia virus isolated from the child's lesions, giving about 15 pocks on the chorioallantoic membrane. The serum-virus mixture and another with non-immune rabbit serum in place of the human serum, were incubated at $37^{\circ} \mathrm{C}$. for 30 minutes and inoculated on to chorioallantoic membranes of groups of chick embryos. No significant difference in pock counts was subsequently observed. In the second method a 1/2 dilution of the serum was mixed with that dilution of vaccine lymph (Lister Institute) producing about 100 haemadsorbing foci in a monolayer of Hep2 cells. After incubation for one hour at $37^{\circ} \mathrm{C}$. the mixture and a suitable control were inoculated into tubes of Hep2 cells which were held for two days, then tested with fowl erythrocytes. There was no reduction in the count of foci with the child's serum as compared with the control. Similar tests with serum taken after the treatment with postvaccinial gamma globulin but before the exchange transfusion (see below) showed a reduction of pock count or haemadsorbing foci when the serum was diluted 1 in 5 , but not with higher dilutions. 
After Death. At autopsy specimens were collected from skin and mucosal lesions and from the internal organs. These were titrated for virus content on the chick embryo chorioallantoic membrane and in various types of tissue culture (primary monkey kidney, HeLa and human amnion strain FL). The egg cultures gave the most sensitive results. The virus content of the samples, apart from those from surface lesions, was surprisingly low. This is in contrast to the findings of Apostolov, Flewett and Thompson (1961) in a fatal case of vaccinia where death was accompanied by hyperthermia, and high titres of virus were found in internal organs.

TREaTMENT. In addition to the usual supportive measures and antibiotics, the following lines of treatment were tried:

(1) May 5-June 8, 1960. Intramuscular injections of hyperimmune post-vaccinial gamma globulin (total $11.0 \mathrm{~g}$.$) and of ordinary gamma globulin (24.5 \mathrm{~g}$.).

(2) May 17-June 16, 1960. Peroral and parenteral therapy with the compound $\mathrm{N}$-methylisatin $\beta$-thiosemicarbazone (total dosage $11.0 \mathrm{~g}$.) provided by Dr. D. J. Bauer (Wellcome Laboratories of Tropical Medicine), a chemical which has been shown to be active against vaccinia in mice (Hamre, Brownlee and Donovick, 1951; Bauer, 1955).

(3) On May 27 an exchange transfusion of four pints of fresh blood taken from recently vaccinated healthy adults was given.

(4) May 19, 1960. Transfusion of marrow from a 12-week human foetus. This had been stored at $-80^{\circ} \mathrm{C}$. and the total dose given represented approximately $2 \times 10^{12}$ cells, of which at least $80 \%$ were shown to be viable by the eosin-staining method (Schrek, 1936).

(5) May 23 and May 25, 1960. $4 \mathrm{ml}$. of ground-up spleen and thymus from a 12-week-old, fresh human foetus. A smear from the suspension contained many viable lymphocytes.

(6) May 30-June 20, 1960. Daily intramuscular injections of $10 \mathrm{ml}$. of ground-up splenic tissue. The spleen had been removed from a healthy young adult injured in a motor cycle accident. The ground-up organ was stored at $-80^{\circ} \mathrm{C}$.

It was noteworthy that no systemic upset was produced by any of these forms of treatment. Fresh vesicles appeared while the therapy outlined in items (1)-(5) was pursued and it was quite evident that they had no lasting effect in containing the spread of the disease. After the exchange transfusion, however, there was a short-lived inflammatory reaction around established and developing skin lesions. After treatment (6) was commenced on May 30 no fresh lesions appeared and there was no further spread of existing lesions. By this time, however, the general condition had deteriorated and the infant gradually grew weaker and died.

Autopsy. He was a moderately jaundiced male infant, weighing 4,500 g. Extensive, ulcerating lesions were seen in many areas, some of them covered by black, crusted scabs.

In the muscle of the abdominal wall there were three areas of haemorrhage; they were sites of injection of splenic suspensions. Aggregates of amorphous yellow material were present in the muscles of the thighs, where the semithiocarbazone had been injected.

A tiny vesicle was seen on the upper surface of the right vocal cord. Two small pustular lesions, each $8 \mathrm{~mm}$. in diameter, were present on the pleural surface, near the apex of the right lung, and a similar lesion was seen on the posterior aspect of the lower lobe of the left lung. An ulcerated lesion involved almost the whole of the hard palate. There was extensive haemorrhage into the wall of the caecum. The liver was bile-stained and obviously fatty. The thymus was not identified. Testes were slightly enlarged and very hard. Other organs were normal in size and appearance. It was noteworthy that lymph nodes were nowhere enlarged.

HistolOGY. In sections from the sites of injection of adult spleen suspension, a few scattered lymphocytes were seen. No lymphocytes were seen in the area where foetal lymphocytes had been injected.

Many sections from the skin ulcers were examined and ballooned epidermal nuclei and cytoplasmic inclusions were features of all (Fig. 4). The lesion on the vocal cord had a similar appearance. The lesions in the lungs consisted of areas of haemorrhagic bronchopneumonia in which numerous large clumps of Grampositive cocci were seen. Their situation and appearance suggested that they were pyaemic abscesses. No evidence of Pneumocystis carinii infestation was seen. Extensive necrosis of tubules was seen in both testes.

The histological appearance of spleen and glands was striking. In both, small lymphocytes were almost entirely absent and they consisted almost entirely of reticulum cells. Through the pulp also, both of the lymph nodes and spleen, very few mature lymphocytes were identified. Fig. 5 shows the contrast between a node from this child and one from a child of similar age who died as a result of bronchopneumonia, and Fig. 6 shows sections of spleen from the same two children. No thymic tissue was identified in blocks from the anterior mediastinum. Lymphoid tissue was not seen in sections from stomach and small and large intestines. In the bone marrow myelopoiesis and erythropoiesis appeared normal, but no lymphocytes were seen. The liver showed fatty change, but scattered small areas of necrosis and plugs of bile in the canaliculi were also seen. The appearances were those of toxic hepatitis. Sections from brain, thyroid, heart, pancreas, adrenals and kidneys were normal.

\section{Discussion}

Several points of interest emerge from the findings in the two patients and in particular from the course of the illness in the infant with progressive vaccinia.

The definition of a normal serum gamma globulin level during infancy is a matter of some difficulty. According to Nelson (1959) the level falls progressively after birth and reaches a value of $150 \mathrm{mg}$. between the second and fourth months and thereafter rises gradually. He states that there is increased susceptibility to infection when the level of gamma 


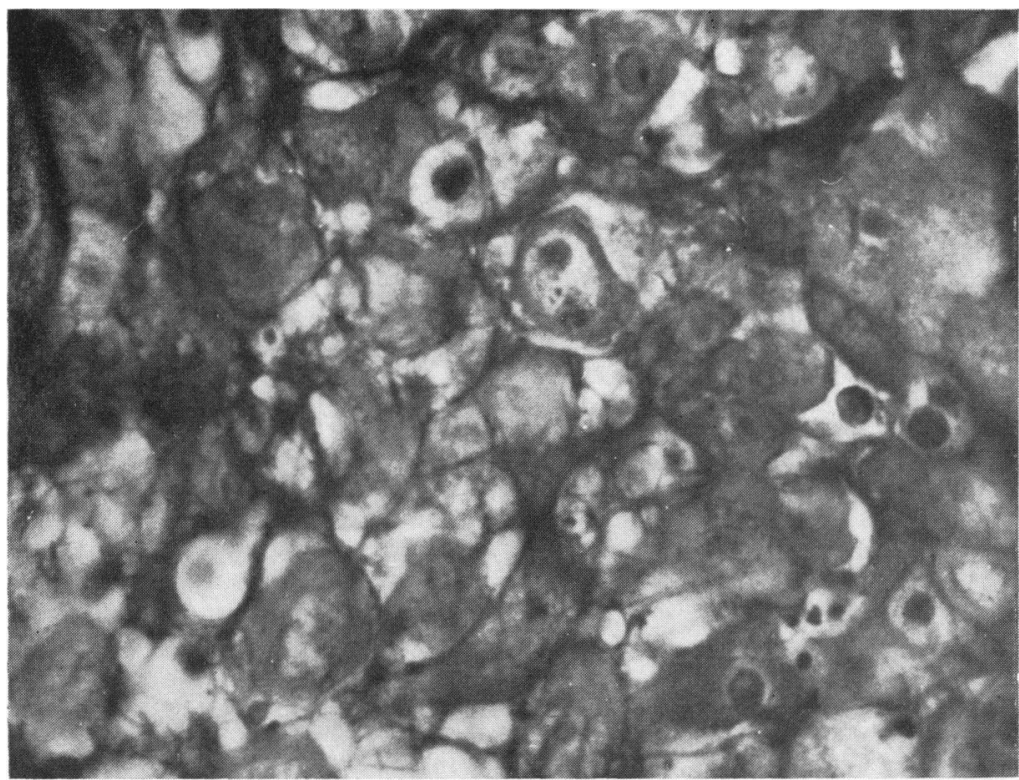

FIG. 4.- Section of a skin lesion from Case 2. (Phloxine-tartrazine $\times 400$.) Ballooned nuclei and cytoplasmic inclusions are seen.

globulin falls below $100-150 \mathrm{mg}$. $/ 100 \mathrm{ml}$. by 2 to 4 months of age. This is in line with the standards adopted by the Medical Research Council Working Party on hypogammaglobulinaemia, which accepts a value of $100 \mathrm{mg} . / 100 \mathrm{ml}$. as indicating hypogammaglobulinaemia in infants less than 1 year old (J. R. Squire, 1962, personal communication).

Probably the gel-diffusion protein technique for estimating gamma globulin is the most accurate of the methods used in the study of this case of progressive vaccinia, and the value of $200 \mathrm{mg}$. $/ 100 \mathrm{ml}$., found by this method before treatment was commenced, is at the lower end of the normal range. Some, or all, of this gamma globulin may have been derived from the mother. The absence of neutralizing antibody to vaccinia virus in the serum sample taken 49 days after vaccination clearly indicates an inability to form antibody, but attempts to compensate for this by giving large doses of gamma globulin, both 'ordinary' and post-vaccinial, neither halted the viraemia nor slowed the evolution of established lesions.

Although some patients with progressive vaccinia have been successfully treated with post-vaccinial gamma globulin (Barbero, Gray, McNair Scott and Kempe, 1955; Kempe, 1960) in others it has not been effective (Keidan, McCarthy and Howarth, 1953; Connolly, Dick and Field, 1962). This suggests that circulating soluble antibody by itself is not decisive. Moreover, it is known that children with hypogammaglobulinaemia or agammaglobulinaemia, although susceptible to repeated bacterial infections, usually recover normally from virus infections such as varicella, herpes simplex and enterovirus infections. Many such children have been vaccinated without developing progressive vaccinia; for example, Kempe (1960) mentions 33 boys with agammaglobulinaemia, who reacted normally to vaccination but did not develop circulating antibody to vaccinia virus. It seems, therefore, that the child with progressive vaccinia associated with hypogammaglobulinaemia (or sometimes with 'normal' gamma globulin levels) is in a special category. In seeking to explain this paradox, Kempe (1960) found that agammaglobulinaemic children with uncomplicated vaccination histories still developed the delayed hypersensitivity response to percutaneous inactivated vaccinia virus, whereas skin-testing of children with progressive vaccinia elicited no hypersensitivity reaction. He describes progressive vaccinia, in a 1-year-old boy, that did not respond to intensive therapy with post-vaccinial gamma globulin, and no skin hypersensitivity reaction was elicited to inactivated vaccinia virus. When a suspension of white cells from the 'buffy coat' layer of the blood of three recently vaccinated donors was injected around the child's vaccination site, regression of lesions occurred, and a delayed hypersensitivity reaction to inactivated vaccinia virus could be elicited in the area of the injections but not 

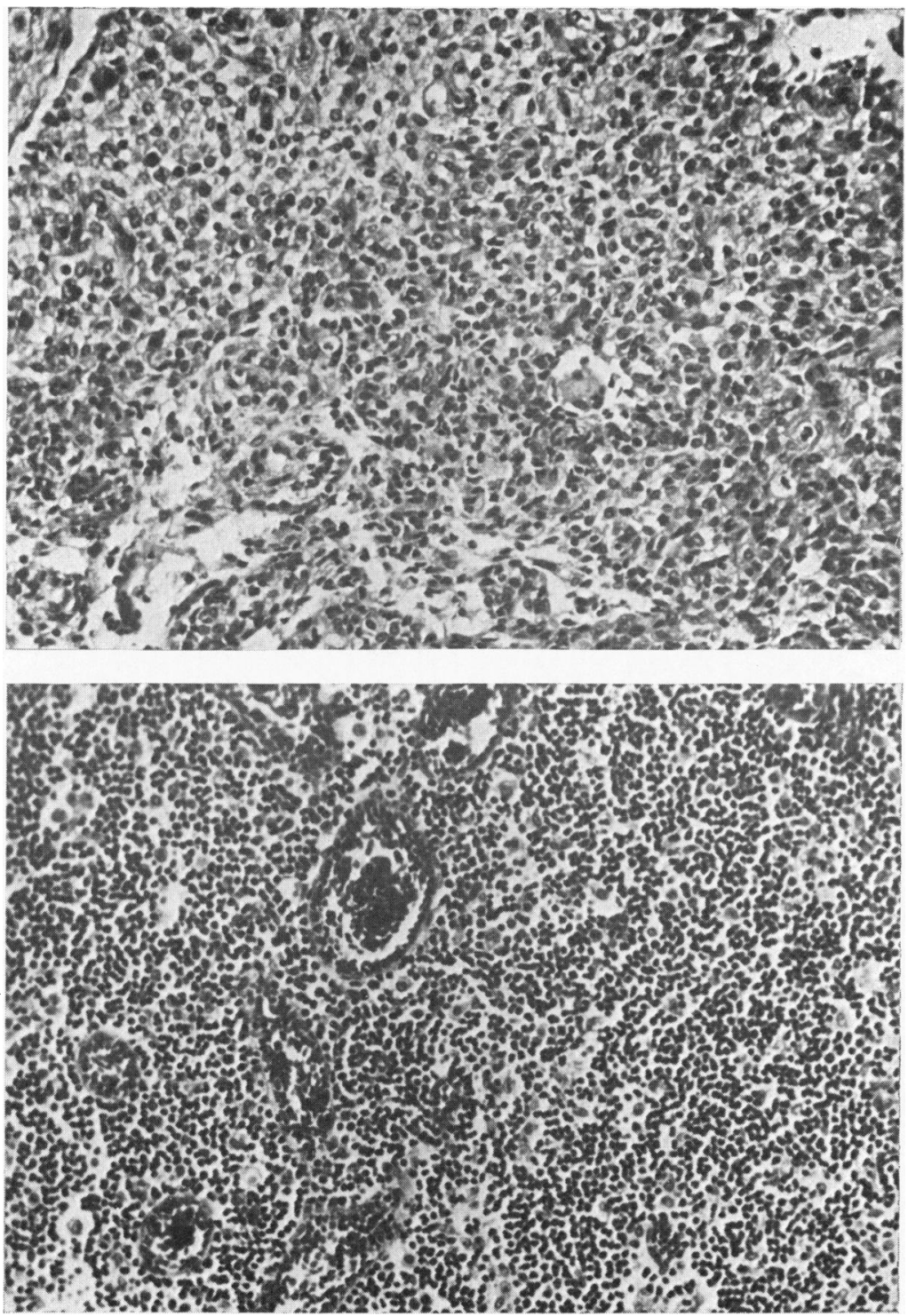

FIG. 5.-Section of axillary gland from Case 2, and below, for comparison, gland from an infant of the same age who died of bronchopneumonia. (H. and E. $\times$ 130.) Only reticulum cells are seen in the gland from Case 2 and there is a striking absence of lymphocytes.

elsewhere on the body. It is significant in this context that an inflammatory response was observed around the lesions of our case on one occasion only and that was after the exchange transfusion of whole blood from recently vaccinated donors.

Delayed hypersensitivity reactions appear to be mediated by cells rather than soluble antibody, probably by immunologically competent cells of the lymphocyte series, although the exact mechanism by which the cells act is still unsettled (Waksman,
Arbouys and Arnason, 1961 ; Najarian and Feldman, 1962). Children with hypogammaglobulinaemia can be made skin-sensitive to dinitrofluorobenzene and their white cells will transfer this sensitivity to normal children. It is also believed that lymphoid cells, from lymph nodes or blood, are concerned in the rejection of skin homografts and this sensitivity can be transferred passively (adoptively) from one animal to another by cells from blood or lymph nodes (Billingham, Silvers and Wilson, 1962). 

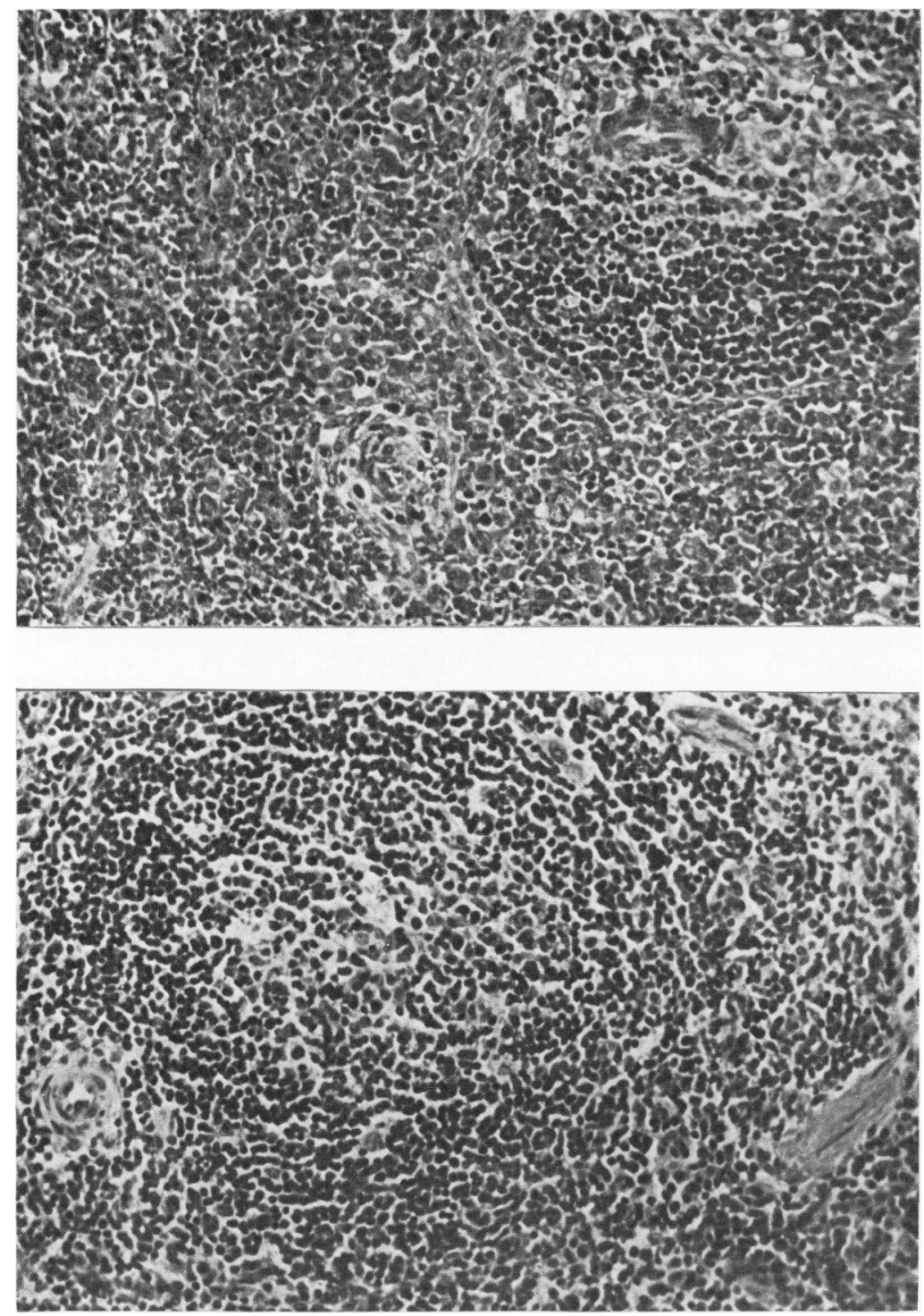

FIG. 6.-Section of spleen from Case 2, and below, spleen from an infant of the same age who died of bronchopneumonia. (H. and E. $\times 130$.) A small Malpighian body is seen in the spleen from Case 2 and mature lymphocytes are very scanty compared with the control.

Children with congenital hypogammaglobulinaemia who exhibit the delayed hypersensitivity reaction may reject skin homografts (Schubert, Fowler, Martin and West, 1960), while those with the rarer form of hypogammaglobulinaemia, in which there is alymphocytosis and no skin hypersensitivity reactions, retain skin grafts (Rosen, Gitlin and Janeway, 1962). As a working hypothesis it might be suggested that the rejection of vaccinia virusinfected cells is mediated through immunologically competent cells of the lymphocyte series and that the occasional child who develops progressive vaccinia has not got this particular component of his or her immune armament. Further, this deficiency may or may not be accompanied by the capacity to form soluble antibody from cells of the plasma cell series.

There is support for this view in that the two cases described in this paper showed a striking absence of lymphocytes around the germinal centres in the 
lymph nodes, in the Malpighian bodies in the spleen and in the inflammatory exudate around the skin lesions. Keidan et al. (1953) and Somers (1957) reported a similar lymphocyte deficiency in their patients with progressive vaccinia, although plasma cells were present in the former case. Other authors (Bigler and Slotkowski, 1951; Kozinn, Sigel and Gorrie, 1955) noted a lymphopenia in their cases.

The reasons for the failure of lymphocyte formation and maturation are not clear, but recent concepts (Miller, 1961 ; Good, Martinez, Archer and Papermaster, 1962; Burnet, 1962) regarding the role of the thymus in lymphocyte maturation may be relevant to the problem. Miller (1961, 1962a, b) showed that mice submitted to thymectomy in neonatal life subsequently have a significant deficiency of small lymphocytes in the peripheral blood, spleen, lymph nodes and Peyer's patches, together with a depression of the immune response to bacterial and viral antigens and to skin homografts, a picture resembling that of 'runt' disease. Loutit (1962) has recently drawn attention to the atrophic lymphatic tissue, including the thymus, in cases described as hereditary lymphoplasmacytic dysgenesis (Hitzig and Willi, 1961): he suggested a genetically determined agenesis of the thymus as the primary fault.

A thorough search in our case of progressive vaccinia did not reveal thymus or thymic tissue in the anterior mediastinum. The size of the thymus may, of course, be reduced at the end of a long, debilitating illness, but in the experience of one of us it is usually possible to find and even weigh the thymus in infants of this age dying from a wide variety of debilitating illnesses. Published autopsy reports on cases of progressive vaccinia generally have not mentioned the thymus, though Bigler and Slotkowski (1951) said that in their patient it was decreased in size. A recent paper by White (1963) reports a fatal case of vaccinia gangrenosa where a lymph follicle hypoplasia was associated with a presumed absence of the thymus. The treatment of this 7-month-old infant followed similar lines to that of our case. The conclusions drawn from such therapy were also in broad agreement.

These findings offer pointers for future investigation and possibly treatment of these cases of progressive vaccinia in infants. It would be of interest to know, for example, whether delayed hypersensitivity reactions to vaccinia and other viruses and to dinitrofluorbenzene are consistently absent, whether there is failure to reject a skin homograft and, in particular, whether thymic tissue is present or not. Treatment might be directed to trying to compensate for the absence of thymic tissue or its lymphocytosis-stimulating factor (Metcalf, 1958) and to supplying lymphocytes.

As Friedman, Baron, Buckler and Steinmuller (1962) have found in guinea-pigs that interferon action rather than antibody or delayed hypersensitivity is apparently more important to recovery from vaccinial infection, it might also be important to investigate the interferon content of the vaccinial lesion in the child with progressive vaccinia.

It is not suggested that all cases of progressive vaccinia can be explained in this way. Those in older children or adults and those complicating leukaemia, malignant lymphoma or other reticuloses may have immune mechanisms that are deranged rather than undeveloped. Such patients might benefit from treatment with post-vaccinial gamma globulin and chemotherapeutic substances such as semithiocarbazone parenterally, or iododeoxyuridine topically (Kaufman, Nesburn and Maloney, 1962; Daly and Jackson, 1962).

\section{Summary}

Pneumocystis carinii infection of the lung and progressive vaccinia are described in siblings.

In the boy with progressive vaccinia the serum gamma globulin level was within the normal range, but vaccinial neutralizing antibody was not detected.

Treatment of the progressive vaccinia case with the drug $\mathrm{N}$-methylisatin $\beta$-thiosemicarbazone and with post-vaccinial and ordinary gamma globulin was ineffective.

At autopsy in both, failure of maturation of lymphocytes from reticulum cells was found and thymic tissue was apparently absent in one of them. The immunological implications of these findings are discussed.

We wish to thank Professor J. R. Squire and Dr. J. F. Soothill of Birmingham University for estimations of gamma globulin; Dr. J. C. Macdonald and Professor A. W. Downie of Liverpool University for supplies of post-vaccinial gamma globulin; Dr. D. J. Bauer of the Wellcome Laboratories of Tropical Medicine for supplies of semithiocarbazone; Professor C. H. Kempe, the University of Colorado, Denver, U.S.A., for much helpful advice; Dr. W. M. Jones, St. James's Hospital, Leeds, for details of the autopsy findings in Case 1; Mr. J. B. Bridges, the Public Health Laboratory Service, Leeds, for help with virology, Mr. Roger Hall, St. James's Hospital, Leeds, for help with haematology, and Mr. J. Hainsworth, St. James's Hospital, Leeds, for the photomicrographs.

\section{REFERENCES}

Apostolov, K., Flewett, T. H. and Thompson, K. S. (1961). Death of an infant in hyperthermia after vaccination. J. clin. Path. 14, 196.

Barbero, G. J., Gray, A., McNair Scott, T. F. and Kempe, H. C. (1955). Vaccinia gangrenosa treated with hyperimmune vaccinal gamma globulin. Pediatrics, 16, 609. 
Bauer, D. J. (1955). The antiviral and synergic actions of isatin thiosemicarbazone and certain phenoxypyrimidines in vaccinia infection in mice. Brit. J. exp. Path., 36, 105

Bigler, J. A. and Slotkowski, E. L. (1951). Smallpox vaccination with prolonged vaccinia. Pediatrics, 7, 24.

Billingham, R. E., Silvers, W. K. and Wilson, D. B. (1962). Adoptive transfer of transplantation immunity by means of blood-borne cells. Lancet, 1,512 .

Burnet, M. (1962). Role of the thymus and related organs in immunity. Brit. med. J., 2, 807.

Connolly, J. H., Dick, G. W. A. and Field, C. M. B. (1962). A fatal case of progressive vaccinia. ibid., 1, 1315.

Daly, J. J. and Jackson, E. (1962). Vaccinia gangrenosa treated with N-methylisatin $\beta$-thiosemicarbazone. ibid., 2, 1300.

Friedman, R. M., Baron, S., Buckler, C. E. and Steinmuller, R. I (1962). The role of antibody, delayed hypersensitivity, and interferon production in recovery of guinea pigs from primary infection with vaccinia virus. J. exp. Med., 116, 347.

Good, R. A., Martinez, C., Archer, O. K. and Papermaster, B. W. (1962). Role of the thymus in development of immunity. J. clin. Invest., 41, 1361.

Hamre, D., Brownlee, K. A. and Donovick, R. (1951). Studies on the chemotherapy of vaccinia virus. II. The activity of some thiosemicarbazones. The activity of some semicarbazones. J. Immunol., 67, 305 .

Hitzig, W. H. and Willi, H. (1961). Hereditäre lympho-plasmocytäre Dysgenesie ('Alymphocytose mit Agammaglobulinämie'). Schweiz. med. Wschr., 91, 1625.

Kaufman, H. E., Nesburn, A. B. and Maloney, E. D. (1962). Cure of vaccinia infection by 5-iodo-2'-deoxyuridine. Virology, $18,567$.

Keidan, S. E., McCarthy, K. and Howarth, J. C. (1953). Fatal generalized vaccinia with failure of antibody production and absence of serum gamma globulin. Arch. Dis. Childh., 28, 110.

Kempe, C. H. (1960). Studies on smallpox and complications of smallpox vaccination. Pediatrics, 26, 176.
Kozinn, P. J., Sigel, M. M. and Gorrie, R. (1955). Progressive vaccinia associated with agammaglobulinemia and defects in immune mechanism. ibid., 16, 600.

Loutit, J. F. (1962). Immunological and trophic functions of lymphocytes. Lancet, 2, 1106

McKay, E. and Richardson, J. (1959). Pneumocystis carinii pneumonia associated with hypogammaglobulinaemia. ibid., 2, 713 .

Metcalf, D. (1958). The thymic lymphocytosis-stimulating factor Ann. N.Y. Acad. Sci., 73, 113.

Miller, J. F. A. P. (1961). Immunological function of the thymus. Lancet, 2, 748 .

- (1962a). Immunological significance of the thymus of the adult mouse. Nature (Lond.), 195, 1318.

(1962b). Effect of neonatal thymectomy on the immunological responsiveness of the mouse. Proc. roy. Soc. B, 156, 415.

Najarian, J. S. and Feldman, J. D. (1962). Passive transfer of transplantation immunity. I. Tritiated lymphoid cells. Il. transplantation immunity. I. Tritiated lymphoid cells. I1.

Nelson, W. E. (1959). Textbook of Paediatrics, 7th ed., p. 256. Saunders, Philadelphia and London.

Rosen, F. S., Gitlin, D. and Janeway, C. A. (1962). Alymphocytosis, agammaglobulinaemia, homografts, and delayed hypersensitivity: study of a case. Lancet, $2,380$.

Schrek, R. (1936). A method for counting the viable cells in normal and in malignant cell suspensions. Amer. J. Cancer, 28, 389.

Schubert, W. K., Fowler, R., Martin, L. W. and West, C. D. (1960) Homograft rejection in children with congenital immunological defects: agammaglobulinaemia and Aldrich syndrome. Plast. reconstr. Surg. (Transplant. Bull.), 26, 125.

Somers. K. (1957). Vaccinia gangrenosa and agammaglobulinaemia. Arch. Dis. Childh., 32, 220.

Waksman, B. H., Arbouys, S. and Arnason, B. G. (1961). The use of specific "lymphocyte" antisera to inhibit hypersensitive reactions of the "delayed" type. J. exp. Med., 114, 997.

White, C. M. (1963). Vaccinia gangrenosa due to hypogammaglobulinaemia. Lancet, 1, 969. 